\title{
Urinary Tract Pain
}

National Cancer Institute

\section{Source}

National Cancer Institute. Urinary Tract Pain. NCI Thesaurus. Code C83493.

Painful sensation in any part of the urinary tract. 